\title{
Membangun Penjelasan dan Sikap Etis Trinitarian terhadap Kejahatan Natural COVID-19
}

\section{Building Trinitarian Explanations and Ethical Attitudes Towards COVID-19 as Natural Evil}

\author{
Thio Christian Sulistio \\ Sekolah Tinggi Teologi SAAT, Indonesia \\ christian.sulistio@seabs.ac.id
}

\begin{abstract}
Abstrak: COVID-19 merupakan kejahatan natural yakni kejahatan yang disebabkan oleh proses natural yang sudah tidak berfungsi sebagaimana mestinya sebagai akibat kejatuhan manusia dalam dosa. Keberadaan COVID-19 sebagai kejahatan natural akan menimbulkan pertanyaan mengapa kejahatan natural dapat ada, untuk apa kejahatan natural ini dan bagaimana akhir dari kejahatan natural ini (problem metafisika kejahatan)? Pertanyaan lain adalah bagaimana respons atau sikap orang-orang percaya terhadap keberadaan kejahatan natural ini (problem moral kejahatan)? Penulis berupaya menjawab dua problem tersebut dengan menggunakan penjelasan trinitarian dari metanarasi Kristen yakni dari sudut providensi Allah, karya Yesus Kristus di salib, dan karya Roh Kudus di dalam gereja Tuhan. Allah di dalam kedaulatan-Nya mengizinkan kejahatan natural COVID-19 untuk kebaikan yang lebih besar. Anak Allah Yesus Kristus mengalahkan kejahatan melalui pelayanan-Nya di bumi dan di Salib. Roh Kudus, yang diutus Bapa dan Anak, menghibur dan memberi kuasa kepada gereja untuk melanjutkan misi Yesus Kristus.
\end{abstract}

Kata-kata kunci: COVID-19, Kejahatan Natural, Problem Kejahatan, Penjelasan Trinitarian, Providensi, Salib Kristus, Roh Kudus.

\begin{abstract}
COVID-19 is a natural evil, namely an evil caused by a natural process that is not functioning properly because of the fall of humans into sins. The existence of COVID-19 as a natural evil will raise the question of why natural evil can exist, what is the purpose of natural evil, and how does this natural evil ends (the metaphysical problem of evil)? Another question is how the response or the attitude of the believers to the existence of this natural evil (the moral problem of evil)? The author tries to answer these two problems by using a trinitarian explanation of Christian metanarrative, namely from the point of God's providence, the work of Jesus Christ on the cross, and the work of the Holy Spirit in the church. God in his sovereignty permits the natural evil of COVID-19 for the greater good. Jesus Christ, the Son of God, triumph over evil through His ministry on earth and on the cross. The Holy Spirit, sent by the Father and the Son, comforts, and empowers the church to continues the mission of Jesus Christ.
\end{abstract}

Keywords: COVID-19, Natural Evil, The Problem of Evil, Trinitarian Explanation, Providence, The Cross of Christ, The Holy Spirit. 


\section{PENDAHULUAN}

Dunia kita saat ini sedang dilanda pandemi akibat merebaknya virus korona yang menyebabkan penyakit pernapasan pada manusia atau COVID-19 ke seluruh dunia. Pandemi ini dipandang sebagai tantangan terbesar yang dihadapi oleh umat manusia sejak perang dunia kedua. Virus ini pada awalnya muncul di Wuhan, provinsi Hubei, Tiongkok pada bulan Desember 2019 dari pasar yang menjual makanan hasil laut termasuk juga kelelawar, kodok, ular, dan burung. ${ }^{1}$ Dari pasar yang menjual hasil tangkapan dari laut ini, virus korona ini kemudian merebak ke seluruh penjuru dunia dan menjadi sebuah pandemi global. Virus ini sampai ke Indonesia dan terdeteksi pertama kalinya pada tanggal 2 Maret 2020 ketika dua warga negara Indonesia tertular oleh seorang warga negara Jepang yang mengunjungi rumah mereka. $^{2}$

Dampak dari virus ini kepada manusia adalah membawa penyakit yang memiliki gejala ringan tidak bergejala, dan bahkan sampai menyebabkan kematian pada penderitanya. Di Indonesia sendiri, sampai pada saat penulis menuliskan artikel ini, diperkirakan ada lebih dari 575 ribu orang yang terpapar penyakit ini dan ada 17 ribu orang lebih yang meninggal dunia akibat penyakit dari virus korona ini. Di seluruh dunia ada 65 juta lebih orang yang terpapar dan ada lebih 1,5 juta orang yang meninggal dunia. ${ }^{3}$ Virus ini telah menyebabkan penderitaan karena sakit dan kematian khususnya di kalangan usia paruh baya dan lanjut usia beserta orang yang memiliki penyakit lainnya seperti diabetes dan darah tinggi. Namun dampak virus ini tidak hanya sampai di sana tetapi juga mengakibatkan kesulitan hidup dalam

${ }^{1}$ Indranil Chakraborty dan Prasenjit Maity, "COVID-19 Outbreak: Migration, Effects on Society, Global Environment and Prevention" Science of Total Environment 728 (2020): 2, diakses 9 Oktober 2020, https://doi.org/10.1016/j.scitotenv. 2020.138882 .

${ }^{2}$ Rebecca Ratcliffe, "First coronavirus cases confirmed in Indonesia amid fears nation is ill-prepared for outbreak," The Guardian, 2 Maret 2020, https://www.theguardian.com/world/ 2020/mar/02/first-coronavirus-cases-confirmed-in-indonesiaamid-fears-nation-is-ill-prepared-for-outbreak, diakses 5 Oktober 2020. bidang ekonomi karena membuat bertambahnya jumlah orang miskin akibat pendapatan yang menurun atau tidak memiliki pekerjaan. Pandemi ini juga menyebabkan tingkat pertumbuhan ekonomi yang menurun sehingga makin banyak yang menganggur bukan hanya di Indonesia tetapi seluruh dunia. ${ }^{4}$

Virus ini jelas menyebabkan penderitaan (suffering) dan kesakitan (pain) kepada manusia. Penderitaan dan kesakitan ini akan membawa kita kepada pertanyaan-pertanyaan yang, di dalam dunia teologi dan filsafat, berkaitan dengan problem kejahatan (problem of evil) yakni bagaimana mendamaikan kepercayaan kita kepada Allah yang baik dan mahakuasa dengan keberadaan kejahatan di dalam dunia ini yang menimbulkan penderitaan dan kesakitan. Problem kejahatan ini sendiri bukan problem yang tunggal tetapi memiliki berbagai macam versi dan cabang. Paling tidak kita dapat membedakan problem eksistensial kejahatan dan problem intelektual kejahatan. ${ }^{5}$

Problem eksistensial kejahatan atau disebut juga sebagai problem religius atau problem praktis kejahatan berbicara tentang bagaimana mempertahankan dan memulihkan relasi dengan Allah di tengah-tengah penderitaan yang dialami oleh orang yang kita kasihi atau kita sendiri, sambil jujur dengan diri dan perasaan kita sendiri. ${ }^{6}$ Problem intelektual kejahatan atau problem kejahatan teoritis berbicara tentang upaya memahami apakah kejahatan dan penderitaan merupakan alasan yang baik dan cukup untuk percaya bahwa Allah yang baik dan Mahakuasa tidak ada. ${ }^{7}$ Problem intelektual kejahatan memiliki dua cabang yakni problem logis atau deduktif kejahatan dan problem evidensial atau induktif kejahatan.

\footnotetext{
${ }^{3}$ Satuan Tugas Penanganan Covid-19, "Data Sebaran Indonesia," https://covid19.go.id, diakses 7 Desember 2020. Seiring jalannya waktu jumlah ini akan bertambah terus sampai ada obat yang dapat menyembuhkan atau vaksin yang memberi kekebalan terhadapnya.

${ }^{4}$ Chakraborty dan Maity, "COVID-19 Outbreak," 3

${ }^{5}$ Chad V. Meister, Evil: A Guide for the Perplexed, edisi kedua (New York: Bloomsbury, 2018), 14.

${ }^{6}$ Daniel Howard-Snyder, "God, Evil, and Suffering," dalam Reason for the Hope Within, ed. Michael J. Murray (Grand Rapids: Eerdmans, 1999), 79.

${ }^{7}$ Ibid.
} 
Problem logis kejahatan hendak menunjukkan secara logis bahwa keberadaan Allah yang mahakuasa dan mahakasih bertentangan atau berkontradiksi secara logis dengan keberadaan kejahatan sehingga menghasilkan kesimpulan bahwa Allah tidak ada. Sedangkan problem evidensial kejahatan hendak menunjukkan bahwa keberadaan kejahatan khususnya kejahatan yang tidak bermakna (gratuitous evil) menunjukkan bahwa mungkin sekali Allah tidak ada. ${ }^{8}$

Di samping adanya problem eksistensial dan problem intelektual yang terkait erat dengan teisme, kita juga berhadapan dengan problem metafisika dan moral kejahatan yang berada di atas dan memayungi problem eksistensial dan problem intelektual yang terkait dengan segala wawasan dunia (worldview). ${ }^{9}$ Problem metafisika kejahatan berkaitan dengan pertanyaan natur, asal mula, makna/tujuan, serta akhir dari kejahatan. Dengan kata lain problem ini berkaitan dengan pertanyaan mengapa kejahatan muncul dan ada di dalam dunia ini dan bagaimana dengan akhir dari kejahatan ini? Pertanyaan ini, sama seperti pertanyaan tentang asal dan natur dunia ini, tidak terbatas hanya kepada teisme tetapi juga kepada semua wawasan dunia apakah itu naturalisme, panteisme, dan panenteisme. Semua wawasan dunia perlu memahami dan menjelaskan asal, natur, makna dan akhir dari penderitaan itu sendiri. Sedangkan problem moral berkaitan dengan bagaimana respons moral orang yang memiliki pandangan dunia tertentu tersebut terhadap adanya kejahatan. Apakah ada kewajiban moral untuk memberikan respons pada kejahatan ${ }^{10}$

Mengetahui berbagai macam bentuk dan cabang problem kejahatan ini penting agar kita dapat memberikan jawaban yang tepat kepada masingmasing problem tersebut. Orang yang mengalami

\footnotetext{
${ }^{8}$ Meister, Evil, 22-32. Pada saat ini telah ada konsensus bahwa problem logis kejahatan telah berhasil dijawab oleh Alvin Plantinga di dalam bukunya God, Freedom, and Evil (Grand Rapids: Eerdmans, 1977). Sehingga kebanyakan teolog dan filsuf pada saat ini lebih berfokus kepada problem evidensial kejahatan. Lihat Meister, Evil: A Guide, 27; Alvin Plantinga, Warranted Christian Belief (Oxford: Oxford University Press, 2000), 461-462.

${ }^{9}$ Ronnie P. Campbell, Worldviews and Problem of Evils: A Comparative Approach (Bellingham: Lexham, 2019), 22-23,
}

penderitaan dan problem eksistensial kejahatan tidak akan menemukan penghiburan dan jawaban pada waktu kita menyodorkan pembelaan kehendak bebas (free will defense) atau pembelaan kebaikan yang lebih besar (greater good defense). Orang tersebut membutuhkan penghiburan dan kehadiran orang-orang yang mengasihi dia. Sebaliknya orang yang bergumul dengan problem intelektual membutuhkan jawaban intelektual yang baik bukan sekedar kehadiran dan kata-kata yang menghibur. ${ }^{11}$ Perbedaan ini juga penting agar pada waktu kita memberikan penilaian berhasil atau tidaknya sebuah jawaban atau teodisi pada satu bentuk problem kejahatan. Kegagalan sebuah pembelaan dan teodisi yang ditujukan untuk menjawab problem intelektual untuk memberikan penghiburan dan ajakan untuk bertindak menolong orang lain yang menderita (menjawab problem eksistensial dan moral kejahatan) bukan berarti pembelaan tersebut gagal dalam menjawab problem intelektual kejahatan. Tidak ada satu pembelaan atau teodise yang dimaksudkan untuk menjawab semua problem kejahatan. John Feinberg menjelaskan: "It is wrongheaded at a very fundamental level to think that because a given defense or theodicy doesn't solve every problem of evil, it doesn't solve any problem of evil." 12

Artikel ini sendiri berupaya menjawab problem metafisika dan moral dari kejahatan khususnya kejahatan karena COVID-19. Problem metafisika kejahatan COVID-19 dapat muncul dalam bentuk pertanyaan: Mengapa penyakit COVID-19 ini bisa muncul jika Allah yang baik itu ada? Apa makna dari penderitaan dan sakit yang disebabkan oleh COVID-19 ini? Problem moral kejahatan berkaitan dengan COVID-19 muncul dalam bentuk pertanyaan moral yakni: Bagaimana kita sebagai orang Kristen memberikan respons moral yang tepat terhadap penderitaan akibat penyakit

Logos Bible Software. Peter van Inwagen juga menyetujui adanya problem ini, lihat Peter van Inwagen, The Problem of Evil (Oxford: Clarendon, 2008), 155, catatan 20.

${ }^{10}$ Campbell, Worldviews and Problem of Evil, 23.

${ }^{11}$ John S. Feinberg, The Many Faces of Evil: Theological Systems and the Problems of Evil, edisi revisi (Wheaton: Crossway, 2004), 25-26; Howard-Snyder, "God, Evil, and Suffering," 79.

${ }^{12}$ Ibid., 27. Penekanan oleh penulis buku. 
COVID-19? Adakah kewajiban moral kita untuk memberikan respons terhadap COVID-19 ini? Untuk menjawab pertanyaan-pertanyaan tersebut penulis pertama-tama akan menjelaskan letak COVID-19 ini di dalam problem kejahatan dengan memaparkan pengertian dan jenis-jenis kejahatan, dan perbedaan antara kejahatan dengan penderitaan dan kesakitan. Bagian ini berguna untuk mengerti natur dan karakteristik COVID19 sebagai kejahatan. Kedua, penulis akan memberikan penjelasan trinitarian yang berdasar kepada metanarasi Kristen di dalam Alkitab kepada keberadaan COVID-19 ini serta menjawab bagaimana sikap moral orang Kristen berhadapan dengan problem penderitaan COVID-19 ini.

\section{COVID-19 SEBAGAI KEJAHATAN NATURAL YANG MENIMBULKAN PENDERITAAN DAN KESAKITAN}

Di dalam bagian ini penulis akan menempatkan COVID-19 ini di dalam konteks natur dan jenis kejahatan serta perbedaan kejahatan dengan penderitaan dan kesakitan.

\section{Natur Dari Kejahatan (Evil)}

Pada umumnya orang-orang Kristen menganut pandangan klasik tentang kejahatan yang berakar di dalam pandangan Agustinus dan diteruskan oleh Thomas Aquinas, Martin Luther, John Calvin, dan C.S. Lewis. Di dalam pandangan ini kejahatan dianggap sebagai kekurangan dari kebaikan atau ketiadaan kebaikan (privatio boni) di mana kebaikan diidentikkan dengan keberadaan itu sendiri. ${ }^{13}$ Kejahatan tidak pernah eksis di dalam dirinya sendiri tetapi bersifat parasitik pada kebaikan yang memiliki keberadaan, tatanan, bentuk, dan ukuran. Kejahatan berarti hilangnya keberadaan, tatanan, bentuk, dan ukuran yang seharusnya ada pada ciptaan. Kejahatan buta, misalnya, adalah kurangnya penglihatan pada manusia yang seharusnya memiliki penglihatan

\footnotetext{
${ }^{13}$ Phillip Cary, "A Classic View," dalam God and the Problem of Evil: Five Views, ed. Chad Meister dan James Dew (Downers Grove: InterVarsity, 2017), 14, Kindle; Campbell, Worldviews and The Problems of Evil, 5, 12.

${ }^{14} \mathrm{John}$ Hick, Evil and the God of Love (New York: Palgrave Macmillan, 2010), 55-57; John M. Frame, "The Problem of
}

tetapi bukan kejahatan pada pohon yang memang tidak harus memiliki penglihatan. Namun pandangan ini perlu dianggap memiliki kelemahan oleh beberapa cendekiawan Kristen seperti John Hick dan John M. Frame di mana mereka berpandangan bahwa konsep ini secara empiris kurang memahami natur kejahatan yang nyata di dalam pengalaman manusia. ${ }^{14}$ Sebagai contoh, rasisme bukan hanya kekurangan kebaikan hati dan simpati namun sesuatu dengan kekuatan jahat dibaliknya.

Berkaitan dengan kritikan tersebut konsep kejahatan sebagai kekurangan kebaikan perlu diperbaiki. Allah secara absolut adalah baik dan segala sesuatu yang diciptakan oleh Allah pada awalnya adalah baik dalam kapasitasnya sebagai ciptaan (Kej. 1:31; 1Tim. 4:4). Kebaikan ciptaan di sini dipahami bukan hanya secara metafisika yakni bahwa ciptaan ada dalam tatanan, bentuk, dan ukuran tetapi juga baik dalam pengertian ciptaan berfungsi sebagaimana mestinya sesuai dengan rancangan Allah. Ciptaan disebut baik berarti ciptaan Allah berfungsi sesuai dengan rancangan Allah di dalam sebuah sistem yang tertata yakni di dalam relasi dengan manusia dan kebudayaannya. Akibatnya, baik bukan hanya dipahami secara metafisika, tetapi juga secara fungsional. ${ }^{15}$

Lebih jauh, Allah merancang dua sistem yang tertata yakni tatanan natural dan tatanan moral. Tatanan natural adalah tatanan yang Allah buat agar ciptaan berfungsi dan beroperasi dengan cara tertentu seperti beroperasi sesuai dengan prinsip-prinsip dan hukum-hukum alam dan beroperasi sebagaimana layaknya alam yang normal berfungsi. Di dalam tatanan natural ini kebaikan dijelaskan oleh Campbell sebagai berikut: "The emphasis on goodness, then, is not so much on how God brought about order within creation (whatever that may include), but, rather, that there is order to the way things are to function in the world that God has made." "16 Tatanan moral

Evil," dalam Suffering and the Goodness of God, ed. Christopher W. Morgan dan Robert A. Peterson (Wheaton: Crossway, 2008), 150-152.

${ }^{15}$ Campbell, Worldviews and The Problems of Evil, 10-11.

${ }^{16}$ Ibid., 12. Penekanan oleh penulis buku. 
penciptaan berkaitan dengan penetapan Allah agar beberapa makhluk ciptaan-Nya yang memiliki kapasitas moral melakukan tindakantindakan moral yang signifikan untuk berfungsi di dalam sebuah cara tertentu di dalam konteks yang lebih luas yakni tatanan natural. Di sini makhluk moral berfungsi sesuai dengan rancangan Allah terhadap mereka di dalam dunia yang memiliki hukum-hukum moral di dalamnya. Di dalam tatanan moral ini kebaikan merujuk kepada "the order in which moral agents are intended to function within the world that God has made."17 Jika kebaikan dipahami seperti di atas maka kejahatan sebagai lawan dari kebaikan dipahami bukan hanya sebagai korupsi terhadap ciptaan yang baik tetapi juga sebuah kekacauan terhadap tatanan dan fungsi yang telah Allah tetapkan terhadap sesuatu di dalam ciptaan. Kejahatan dipahami sebagai kurangnya kebaikan dari sesuatu dan juga absennya kebaikan yang berkaitan dengan intensi Allah terhadap tatanan ciptaan-Nya khususnya tatanan moral. Kejahatan adalah kurangnya kebaikan dan juga ketika ciptaan tidak berfungsi atau beroperasi sebagaimana seharusnya ciptaan berfungsi. Campbell menjelaskan: "evil is not merely the privation of the good of some "thing" but can also be ascribed to the absence of some good as it relates to God's intentions for the created order, particularly the moral order." 18

Kejahatan itu sendiri terbagi ke dalam kejahatan moral dan kejahatan natural. Kejahatan moral adalah kejahatan yang disebabkan oleh orangorang yang bebas baik secara sengaja maupun dengan tidak sengaja karena melalaikan tanggung jawab mereka. Kejahatan moral ini seperti pembunuhan, pemerkosaan, pencurian, rasisme, eksploitasi terhadap sesama manusia, dan lain-

\footnotetext{
${ }^{17}$ Ibid. Penekanan oleh penulis buku.

${ }^{18}$ Ibid., 13. Penekanan oleh penulis buku.

${ }^{19}$ Greg Welty, Why is There Evil in the World (And so Much of it)? (Ross-shire: Christian Focus, 2018), 28-29.

${ }^{20}$ Feinberg, The Many Faces of Evil, 193. Perlu diperhatikan juga bahwa kejahatan natural kadang kala bercampur dengan kejahatan moral. Bencana alam yang disebabkan oleh ulah manusia seperti banjir karena saluran air yang terhambat, pemanasan global, bencana kekeringan karena kurangnya ruang hijau dan penyerapan air termasuk ke dalam kejahatan natural yang disebabkan oleh kejahatan manusia.
}

lain. ${ }^{19}$ Kejahatan natural adalah kejahatan yang disebabkan oleh obyek-obyek atau kekuatankekuatan yang bersifat impersonal dan bukan oleh makhluk berpribadi. Kejahatan natural termasuk penyakit dan cacat yang disebabkan oleh kegagalan genetika, bencana alam yang disebabkan oleh proses di dalam alam itu sendiri dan di luar diri manusia, dan penyakit baik oleh virus maupun bakteri. ${ }^{20}$ Contoh-contoh kejahatan natural adalah gempa bumi, tsunami, down syndrome, kanker, dan penyakit COVID-19 yang disebabkan oleh virus korona.

Selain kedua jenis kejahatan tersebut, ada jenis kejahatan lain yaitu kejahatan tanpa makna (gratuitous evil) atau kejahatan yang sangat buruk (horrendous evil). Kejahatan yang tak bermakna adalah kejahatan-kejahatan yang sangat buruk sekali sehingga dipandang tidak memiliki justifikasi, jaminan (warrant), atau alasan yang mendasarinya bagi Allah untuk mengizinkannya. Kejahatan-kejahatan tersebut dipandang tidak menghasilkan kebaikan yang lebih besar (greater good) atau juga tidak menghalangi kejahatan yang lebih buruk terjadi, dan malah sebaliknya kejahatan tersebut dipandang tidak memiliki makna sama sekali. ${ }^{21}$

\section{Kejahatan, Penderitaan (Suffering) dan Kesakitan (Pain)}

Problem kejahatan sangat terkait dengan masalah penderitaan dan kesakitan. Problem kejahatan akan menjadi problem jika muncul penderitaan terhadap manusia. Kejahatan natural tidak akan menjadi problem kejahatan jika tidak ada manusia atau makhluk hidup yang mengalami penderitaan akibat angin tornado, virus, dan gunung meletus. Tornado yang terjadi di lautan Pasifik

\footnotetext{
${ }^{21}$ Campbell, Worldviews and the Problem of Evil, 218. Contoh kejahatan ini adalah: memperkosa seorang wanita dan memotong lengannya, penyiksaan psikologis dengan tujuan disintegrasi kepribadian, skizofrenia, depresi klinis berat, memakan keturunannya sendiri, pelecehan anak, inses dengan orang tua sendiri, partisipasi di dalam kamp konsentrasi Nazi Jerman. Lih. Marilyn McCord Adams, Christ and Horrors: The Coherence of Christology (Cambridge: Cambridge University Press, 2006), 32-33
} 
dan jauh dari kediaman manusia tidak akan memunculkan problem kejahatan. Demikian juga di dalam kejahatan moral yang menjadi perhatian utama kita adalah penderitaan yang disebabkan oleh kejahatan tersebut. ${ }^{22}$ Dengan demikian, untuk memahami hakikat problem kejahatan, kita juga perlu memahami hakikat penderitaan dan kesakitan. Jika demikian apa yang dimaksud dengan penderitaan dan kesakitan?

Penderitaan dan kesakitan sering kali disamakan namun kesakitan dan penderitaan adalah dua hal yang berbeda. Kesakitan dapat berupa kesakitan fisik di mana kita merasakan sakit akibat adanya kerusakan pada jaringan tubuh kita. Kesakitan dapat pula berupa kesakitan mental atau psikologis yang terkait erat dengan kesakitan yang berorientasi emosional dan psikologis di mana seseorang mengalami perasaan-perasaan dan emosi-emosi negatif yang kuat seperti kesedihan dan penyesalan. Meski pada umumnya kesakitan menyebabkan penderitaan dipandang jahat akan tetapi tidak semua kesakitan, khususnya kesakitan fisik, menyebabkan penderitaan. Kesakitan yang dialami oleh seorang atlet di dalam masa latihannya atau ibu yang memilih melahirkan dengan cara normal bukan dianggap sebagai bagian dari masalah kejahatan. ${ }^{23}$

Penderitaan manusia berkaitan dengan perkembangan manusia menjadi manusia seutuhnya dan sepenuhnya (human flourishing) dan keinginan hati manusia terdalam terhadap sesuatu (bisa benda, manusia yang lain, nilai-nilai, cita-cita) yang sangat ia hargai dan kasihi sehingga menimbulkan komitmen yang kuat terhadapnya (the desire of a person's heart). Penderitaan

\footnotetext{
${ }^{22}$ Eleonore Stump, Wandering in Darkness: Narrative and the Problem of Suffering (Oxford: Clarendon Press, 2010), 4.

${ }^{23}$ Stump, Wandering in Darkness, 5-6.

${ }^{24}$ Ibid., 11. Konsep penderitaan ini penting berkaitan dengan alasan mengapa Allah mengizinkan kejahatan yakni karena adanya kebaikan yang lebih besar. Kebaikan ini haruslah dapat mengalahkan penderitaan manusia dalam kaitan dengan perkembangan manusia sepenuhnya dan seutuhnya serta apa yang menjadi keinginan hati manusia yang paling mendalam. Stump selanjutnya membagi perkembangan manusia sepenuhnya dan seutuhnya dalam tiga aspek yakni aspek perkembangan fisik, mental, dan personal. Aspek fisik adalah kondisi di mana manusia tidak memiliki halangan di dalam perkembangan fisiknya. Aspek mental adalah kondisi di mana
}

terjadi ketika manusia dihancurkan kesempatan dan kemampuan dia untuk menjadi manusia sepenuhnya dan seutuhnya serta ketika apa yang menjadi keinginan hatinya yang paling mendalam dirampas dan tidak dapat ia capai. Stump memberikan definisi penderitaan demikian: "The evil human beings endure constitutes suffering for them because it goes contrary to human flourishing or contrary to the core desires of the will of the sufferer or both." ${ }^{24}$ Dari pemaparan ini maka kita dapat mengatakan bahwa COVID-19 adalah kejahatan natural yang disebabkan oleh virus korona yang menyebabkan penderitaan dan sakit kepada manusia. COVID19 adalah kejahatan natural karena virus korona yang tidak beroperasi sebagaimana mestinya di dalam tatanan natural yang Allah rancang pada awalnya. Penyakit ini menimbulkan penderitaan pada manusia karena penyakit ini menghambat manusia bertumbuh sepenuhnya dan seutuhnya serta merampas apa yang hati manusia hargai dan cintai serta menimbulkan kesakitan kepada penderitanya.

\section{PENJELASAN TRINITARIAN TERHADAP COVID-19}

Setelah memetakan COVID-19 ke dalam problem metafisika dan moral kejahatan serta menempatkan COVID-19 sebagai kejahatan natural yang membawa penderitaan dan kesakitan maka penulis akan mencoba memberikan penjelasan (explanation) secara teologis mengapa COVID19 hadir di dalam kehidupan manusia meskipun ada Allah yang baik dan mahakuasa. Penjelasan seperti ini berbeda dengan teodise (theodicy) dan pembelaan (defense). ${ }^{25}$ Kedua pendekatan tersebut

orang tidak mengalami halangan di dalam perkembangan mentalnya. Aspek personal yakni tidak adanya hambatan di dalam relasi kasih khususnya relasi dengan Allah yang dianggap perkembangan manusia yang paling tinggi di dalam kekristenan. Eleonore Stump, "Suffering and Flourishing," (Makalah yang dipresentasikan pada Kuliah M.Th, Singapore Bible College, 21 September 2020), 2-5.

${ }^{25}$ Adams, Christ and Horrors, 43. Sejak Alvin Plantinga mempublikasikan bukunya God, Freedom, and Evil maka orang terbiasa membedakan antara teodisi dan pembelaan. Teodisi (theodicy), istilah yang pertama kali diperkenalkan oleh Gottfried Leibniz seorang filsuf Jerman, berasal dari dua kata Yunani Theos (Allah) dan dike (keadilan) sehingga makna teodisi adalah upaya untuk menunjukkan bahwa Allah adalah 
adalah pendekatan yang umum di dalam menghadapi problem kejahatan. Namun, berhadapan dengan problem metafisika dan moral kejahatan, penulis tidak akan menggunakan kedua pendekatan tersebut tetapi menggunakan pendekatan yang diusulkan oleh Marilyn McCord Adams sebagai pendekatan ketiga yakni memberikan sebuah penjelasan khususnya memberikan alasanalasan yang menjelaskan (explanatory reasons), bukan alasan-alasan yang membenarkan (justifying reasons) mengapa Allah mengizinkan kejahatan natural ini ke dalam dunia. Alasan-alasan yang menjelaskan ini dapat berupa konsep teologis bahwa Allah menciptakan dunia untuk kemuliaan Allah, kehendak Allah agar manusia sebagai gambar dan rupa Allah masuk ke dalam persekutuan dengan Dia, Allah hendak menyediakan penebusan di dalam Kristus, dan Allah menyertakan manusia di dalam memusnahkan kejahatan. $^{26}$

Penulis menggunakan penjelasan dari perspektif Kristen khususnya dari doktrin Allah Tritunggal sebagaimana yang dinyatakan di dalam narasi Kristen sehingga penulis menyebut penjelasan ini sebagai penjelasan trinitarian. Mengapa menggunakan perspektif Allah Tritunggal di dalam memberikan penjelasan? Pertama, karena doktrin Allah Tritunggal merupakan doktrin mendasar di dalam iman Kristen yang membedakan iman

adil dan memiliki alasan moral yang cukup ketika Ia mengizinkan kejahatan. Sebuah teodisi bertujuan "to vindicate the reality of God by providing a plausible explanation for evil." Meister, Evil: A Guide, 42, penekanan oleh penulis buku. William Hasker selanjutnya membuat perbedaan antara teodisi kebijakan-umum (general-policy theodicy) dengan teodisi kebaikan-spesifik (specific-benefit theodicy). Teodisi kebijakanumum berupaya membenarkan tindakan Allah mengizinkan kejahatan tertentu sebagai konsekuensi dari kebijakan umum yang Allah ambil, sebagai Pribadi yang mahabijak dan mahabaik. Sedangkan teodisi kebaikan-spesifik berupaya untuk menjustifikasi tindakan Allah mengizinkan kejahatan tertentu dengan menunjukkan kebaikan yang timbul atau kejahatan yang lebih besar yang dapat dihindarkan. William Hasker, "An Open Theist View," dalam God and The Problem of Evil, 61. Lih. juga Welty, Why Is There Evil, 168-171.

Berbeda dengan teodisi, pembelaan tidak mengklaim memberikan serangkaian alasan yang sesungguhnya mengapa Allah mengizinkan atau membiarkan kejahatan. Pembelaan hanya bertujuan untuk membantah argumen dari problem kejahatan (seperti argumen logis atau evidensial) dengan menyangkal kebenaran dari premis-premis di dalam argumen tersebut. Pembelaan lebih ringan tugasnya karena pembelaan
Kristen dengan iman kepercayaan lain sehingga pada waktu kita menjelaskan tentang problem kejahatan dari perspektif Kristen kita dapat mendasarkan penjelasan tersebut kepada doktrin Allah Tritunggal. Banyak teodisi atau pembelaan yang dibangun oleh orang-orang Kristen untuk menjawab problem kejahatan khususnya COVID19 hanya bersifat umum sampai kepada konsep Allah yang umum sehingga teodisi, penjelasan, atau pembelaan yang diberikan tidak cukup menggambarkan seluruh metanarasi Kristen tentang penciptaan, kejatuhan dalam dosa, penebusan Kristus, Pentakosta, dan restorasi. ${ }^{27}$ Kedua, penjelasan trinitarian merupakan penjelasan yang kokoh, menyeluruh, dan tuntas pada waktu kita berbicara tentang problem kejahatan. Di dalam penjelasan trinitarian kita berbicara tentang Allah yang berdaulat, Allah yang berinkarnasi, dan Allah yang memampukan kita manusia (empowering people) dalam menghadapi COVID-19. Penjelasan trinitarian lebih setia menggambarkan narasi Kristen yang berbicara tentang Allah yang berdaulat, Allah yang bertindak, dan Allah yang mengalahkan kejahatan.

\section{KEDAULATAN ALLAH ATAS KEJAHATAN NATURAL COVID-19}

Di dalam teologi Kristen asal muasal dari kejahatan natural dijelaskan sebagai akibat dari

tindak berupaya menunjukkan serangkaian alasan mengapa Allah mengizinkan kejahatan tertentu atau memberikan solusi untuk problem kejahatan. Chad Meister dan James K. Dew, "Introduction," dalam God and The Problem of Evil, 6-7.

${ }^{26}$ Ibid. Karena kehadiran kejahatan yang setua umur manusia maka tiap wawasan dunia dan agama telah mencoba menjawab dan menjelaskan problem kejahatan ini dengan cara masing-masing. Penjelasan ini berfungsi untuk memberikan makna kepada penderitaan dan kesakitan ini. Penjelasan juga menolong orang untuk bertindak sesuai dengan keyakinan orang tersebut terhadap makna penderitaan. Membiarkan orang-orang yang menderita tanpa penjelasan kepada makna penderitaannya bahkan dengan membangun sikap anti penjelasan kejahatan adalah sebuah kejahatan juga. Timothy Keller menjelaskan: "When no explanation at all is givenwhen suffering is perceived as simply senseless, a complete waste, and inescapable - victims can develop a deep, undying anger and poisonous hate that was called ressentiment by Friedrich Nietzsche, Max Weber, and others." Timothy Keller, Walking with God through Pain and Suffering (London: Hodder \& Stoughton, 2013), 14. Penekanan oleh penulis buku.

${ }^{27}$ Campbell, Worldviews and The Problem of Evil, xii. 
kejatuhan manusia ke dalam dosa. Allah menciptakan dunia serta isinya yang amat baik pada mulanya (Kej. 1:25, 31). Namun manusia dengan kemauannya memilih untuk tidak menaati Allah dan berdosa terhadap Allah. Kejahatan natural adalah kutukan Allah terhadap alam semesta sebagai hukuman terhadap manusia pertama yang jatuh dalam dosa. ${ }^{28}$ Sebagai akibat kejatuhan manusia dalam dosa maka manusia (Adam dan Hawa dan keturunannya) akan mengalami kematian fisik (Kej. 2:16-17; 3:19; Rm. 5:12) dan kematian spiritual. ${ }^{29}$ Kematian fisik yang dapat disebabkan oleh penyakit, bencana alam, dan proses penuaan. Kejatuhan manusia dalam dosa juga membawa konsekuensi terhadap tatanan natural alam (natural order). Allah menempatkan manusia ke dalam dunia di mana manusia dapat hidup dan berfungsi dengan baik sesuai dengan rancangan Tuhan kepada mereka di dalam dunia tersebut. Dunia yang beroperasi dengan berbagai macam proses natural yang cocok untuk ditinggali oleh manusia. Namun karena dampak kejatuhan manusia dalam dosa maka kadang-kadang (tidak harus selalu) prosesproses natural tersebut menghasilkan kejahatan natural bagi manusia. Alkitab menggambarkan bahwa karena kejatuhan manusia harus bekerja lebih keras untuk bercocok tanam karena semak duri dan rumput duri juga tumbuh dari tanah yang dikutuk oleh Allah (Kej. 3:17-19). ${ }^{30}$ Paulus menjelaskan dampak kejatuhan manusia terhadap alam lebih lanjut dengan mengatakan bahwa seluruh ciptaan telah ditaklukkan ke dalam kesia-

\footnotetext{
${ }^{28}$ John M. Frame, Apologetics: A Justification of Christian Belief, edisi kedua, ed. Joseph E. Torres (Phillipsburg: P\&R, 2015), 157; Cary, A Classic View," 24-25. Pandangan ini adalah pandangan klasik di dalam kekristenan yang dipegang oleh Agustinus sampai pada teolog-teolog ortodoks hari ini. Namun pandangan tidak menyatakan bahwa kejahatan moral dan natural yang terjadi kepada seseorang pasti merupakan hukuman atas dosa orang tersebut. Kejahatan moral dan natural bisa jadi merupakan hukuman atas dosa partikular tetapi ia tidak harus merupakan hukuman.

${ }^{29}$ David Gooding dan John Lennox, Suffering Life's Pain: Facing the Problems of Moral and Natural Evil (Belfast: Myrtlefield, 2019), 128-130; Feinberg, The Many Faces of Evil, 195. Penulis injili Gavin Ortlund berpendapat bahwa kejahatan natural di dalam dunia ini muncul lebih awal dari kejatuhan manusia di dalam dosa kepada kejatuhan malaikat. Sebuah pandangan yang menarik tetapi sangat spekulatif dan kurang data Alkitab. Lihat Gavin Ortlund, "On the Fall of Angels and the Fallenness of Nature: An Evangelical
}

siaan yakni proses-proses natural yang sebelum kejatuhan manusia dalam dosa bekerja dengan baik telah mengalami penyimpangan yakni tidak berfungsi sebagaimana mestinya sebagaimana yang dirancang oleh Allah dan kadang-kadang proses-proses tersebut mengalami penyimpangan (Rm. 8:18-22) ${ }^{31}$ C.E.B. Cranfield menjelaskan perikop ini dengan baik:

[T] he sub-human creation has been subjected to the frustration of not being able properly to fulfil the purpose of its existence ... We may think of the whole magnificent theater of the universe together with all its splendid properties and all the chorus of sub-human life, created to glorify God but unable to do so fully, so long as man the chief actor in the drama of God's praise fails to contribute his rational part ... [and] so long as man its lord (Gen 1:26, 28; Ps 8:6), is in disgrace." 32

Tatanan natural yang tidak berfungsi sebagaimana mestinya ini menyebabkan terjadinya kesalahan replika sehingga menghasilkan gen yang cacat dan mutasi genetik pada manusia yang menyimpang dan buruk sehingga menghasilkan kecacatan pada manusia. ${ }^{33}$ Tatanan natural ini juga yang menyebabkan virus dan bakteri menjadi virus dan bakteri yang jahat bagi manusia. Mikroba (yakni virus dan bakteri) yang mula-mula baik tetapi karena dampak kejatuhan maka mereka ada yang berubah menjadi virus dan bakteri yang membawa penyakit kepada manusia. ${ }^{34}$ Tatanan natural

Hypothesis Regarding Natural Evil," Evangelical Quarterly 87, no. 2 (2015): 114-136.

${ }^{30}$ Feinberg, The Many Faces of Evil, 195.

${ }^{31}$ Gooding dan Lennox, Suffering Life's Pain, 131. Di dalam pandangan ini binatang karnivora telah ada sejak penciptaan sehingga kematian binatang dan tumbuhan terhadap binatang lain adalah bagian dari sistem alam yang baik yang diciptakan oleh Allah. C. John Collins, Science and Faith: Friends or Foes? (Wheaton: Crossway, 2003), 154.

${ }^{32}$ Gooding dan Lennox, Suffering Life's Pain, 131.

${ }^{33}$ Feinberg, The Many Faces of Evil, 193.

${ }^{34}$ Joe Francis, "Good Design Gone Bad," Answers in Genesis, Oktober 2011, diakses 30 Oktober 2020, https://answersingenesis.org/evidence-for-creation/design-innature/good-designs-gone-bad; David Alinurdin, "COVID-19 dan Tumit Achilles Iman Kristen," Veritas: Jurnal Teologi dan Pelayanan 19, no. 1 (Juni 2020): 6, https://doi.org/10.36421/ veritas.v19i1.373. 
yang umumnya baik ini juga akan menghasilkan proses-proses natural yang membawa kepada gempa bumi dan bencana alam lainnya. Namun sepanjang manusia tidak mengalami penderitaan akibat bencana alam maka bencana alam tidak menjadi problem kejahatan. Kejatuhan manusia dalam dosa membuat proses-proses natural tersebut dapat menyebabkan penderitaan dan kematian pada manusia. ${ }^{35}$

Teologi Kristen juga menjelaskan bahwa Allah adalah Allah yang berdaulat atas segala sesuatu termasuk kejahatan moral dan natural termasuk COVID-19. Kekristenan percaya bahwa alam semesta ini bersifat personal di dalam pengertian bahwa alam semesta pada dasarnya ditata dan dikelola oleh Allah yang berpribadi bukan sebuah kekuatan kosmik yang bersifat impersonal seperti nasib, takdir, kebetulan atau chaos. Pengelolaan dan penataan Allah atas alam semesta ini dikenal juga sebagai providensi Allah. Providensi Allah merupakan tindakan Allah yang berkelanjutan untuk memelihara keberadaan segala ciptaanNya, baik alam dan manusia, serta membawa seluruh ciptaan-Nya kepada tujuan-tujuan yang

\footnotetext{
${ }^{35}$ Penulis menganut pandangan progressive creationism yakni penciptaan dalam jangka waktu yang panjang. Lih. Millard J. Erickson, Christian Theology, edisi ketiga (Grand Rapids: Baker, 2013), 353-354, 398, 446-447. Pandangan ini mengakui bahwa hukum-hukum alam beserta dengan segala konstantanya merupakan hasil ciptaan Allah yang baik. Namun proses natural yang menata dan mengoperasikan alam semesta ini juga memiliki dampak yang lebih menimbulkan penderitaan bahkan kematian kepada manusia yang sudah jatuh dalam dosa dibandingkan dengan sebelum kejatuhan.

${ }^{36}$ Erickson, Christian Theology, 359.

${ }^{37}$ Pandangan ini disebut juga sebagai determinisme ilahi atau determinisme teologis. Untuk penjelasan lebih jauh tentang determinisme teologis lihat Matthew James Hart, "Theological Determinism and the Goodness of God" (disertasi, University of Liverpool, 2019), 15-17. Providensi Allah yang bersifat komprehensif ini disebut juga sebagai providensi Allah yang bersifat spesifik yang berlawanan dengan pandangan providensi yang bersifat umum. Pandangan providensi spesifik (atau providensi detail) percaya bahwa skop providensi Allah mencakup segala sesuatu yang terjadi termasuk hal-hal yang nampak tidak terlalu signifikan seperti rambut di kepala kita (Mat. 10:30), dan burung (Mat. 6:26, 10:29). Providensi umum percaya bahwa Allah memiliki tujuan-tujuan yang bersifat umum yang ingin direalisasikan-Nya namun Ia mengizinkan berbagai macam variasi terhadap detail-detail spesifik dari rencana tersebut sesuai dengan kehendak bebas manusia (Erickson, Christian Theology, 369). Di dalam pandangan providensi Allah yang spesifik ini tidak ada kejahatan
}

telah ditetapkan-Nya. ${ }^{36}$ Providensi Allah atas alam semesta dan umat manusia ini bersifat menyeluruh dan tidak ada sesuatu yang terjadi di luar dari kehendak Allah. Segala sesuatu yang terjadi ada di dalam dunia ini memiliki penyebab utama (ultimate cause) di dalam penetapan Allah yang kekal. Di dalam providensi Allah, segala sesuatu yang terjadi termasuk segala hal yang baik dan segala kejahatan di dalam alam semesta ini, ada di dalam penetapan Allah. ${ }^{37}$ Alkitab menggambarkan bahwa Allah berdaulat atas kejahatan moral manusia dan malaikat serta kejahatan natural yang terjadi karena proses alam. ${ }^{38}$ Namun hal ini tidak menjadikan manusia sebagai robot semata karena pandangan ini mengakui peran dari kehendak bebas manusia di dalam providensi Allah maupun juga otonomi relatif yang diberikan Allah kepada proses-proses natural di dalam alam. Pandangan ini disebut sebagai pandangan providensi kompatibilisme di mana kedaulatan Allah di dalam providensi sejalan dengan kehendak bebas manusia. ${ }^{39}$ Providensi Allah yang berdaulat ini juga tidak menjadikan Allah sebagai pencipta dosa atau kejahatan. ${ }^{40}$ Allah mengizinkan kejahatan termasuk kejahatan

yang tidak memiliki makna karena makna semua kejahatan yang diizinkan Allah ada di dalam rencana Allah yang kekal yang penuh dengan hikmat. Karena perbedaan kualitatif antara Allah dan manusia dan adanya dosa manusia maka manusia belum tentu dapat memahami alasan mengapa Allah mengizinkan suatu kejahatan dan bahwa sudah pasti tidak ada tujuan atau makna di dalam kejahatan. Lihat Feinberg, The Many Faces of Evil, 379-382; Ross Inman, "Gratuitous Evil Unmotivated: A Reply to MacGregor," Philosophia Christi 15, no. 2 (2013): 440-441, diakses 9 November 2020, https://doi.org/ $10.5840 / \mathrm{pc} 201315237$.

${ }^{38}$ Welty, Why Is There Evil, 77-101.

${ }^{39}$ John S. Feinberg, No One Like Him (Wheaton: Crossway, 2001), 651-656, 677-734; Donald A. Carson, "BiblicalTheological Pillars Needed to Support Faithful Christian Reflection on Suffering and Evil," Trinity Journal 38NS, no. 1 (2017): 64-65.

${ }^{40}$ Perdebatan apakah konsep providensi yang dianut oleh pandangan Reformed, pandangan yang dianut oleh penulis, menjadikan Allah sebagai pencipta kejahatan merupakan perdebatan yang cukup menarik dan panjang. Di dalam pandangan penulis, ada perbedaan antara ketetapan Allah yang bersifat positif dalam pengertian menyebabkan secara langsung, dengan ketetapan Allah yang bersifat negatif (adanya asimetri di sini) yakni ketetapan Allah untuk membiarkan sebuah kejahatan tanpa mengintervensinya. Selain itu, ada perbedaan antara kausalitas Allah dengan manusia sebagai akibat dari perbedaan kualitatif antara Allah sebagai pencipta dengan manusia sebagai ciptaan. Kausalitas Allah adalah kausalitas 
natural masuk ke dalam dunia ini untuk kebaikan yang lebih besar (greater good). Paul Helm menjelaskan: "Presumably the general character of that reason must be that out of that evil a greater good would come, a good that could not have come, or could not have been as great, if there had not been that evil." 41

Jika Allah mengizinkan kejahatan natural termasuk COVID-19 terjadi maka kebaikan apa yang Allah inginkan melalui munculnya kejahatan natural COVID-19 ini? Di sini penulis hanya memaparkan alasan-alasan yang paling mungkin untuk menjadi penjelasan bagi keberadaan COVID-19 ini (plausible explanatory reasons) mengapa Allah mengizinkan kejahatan natural ini terjadi. Pertama, kejahatan natural ini terjadi sebagai hukuman dari Allah atas orang-orang yang melakukan kejahatan-kejahatan. Di dalam Alkitab Allah adalah Allah yang adil dan menghakimi dosa-dosa manusia dan memandang manusia bertanggung jawab atas perbuatan-perbuatan jahat mereka. Di dalam penghukuman Alah, Allah memakai kejahatan natural untuk menghukum manusia yang berdosa terhadap Dia. ${ }^{42}$ Namun perlu diingat bahwa tidak berarti COVID-19 ini secara global adalah hukuman Allah. Hal ini juga tidak berarti bahwa setiap orang atau sekelompok orang yang mengalami penderitaan karena COVID-19 ini pasti mengalami hukuman Allah. Alkitab menceritakan bahwa penderitaan Ayub (Ayb. 1-2) dan juga penderitaan orang yang mengalami kebutaan di dalam kitab Injil Yohanes (Yoh. 9:1-3) bukan karena dosa mereka. John Piper menjelaskan: "Therefore, while not all suffering is a specific judgment for specific sins, some is." 43

transenden yang menyebabkan segala sesuatu. Allah juga adalah penyebab tidak langsung dan bukan penyebab langsung. Semua ini memperlihatkan bahwa Allah bukan pencipta kejahatan. Untuk penjelasan lebih jauh dan komprehensif lihat Daniel M. Johnson, "Calvinism and the Problem of Evil: A Map of the Territory," dalam Calvinism and the Problem of Evil, ed. David E. Alexander dan Daniel M. Johnson (Eugene: Pickwick, 2016), 19-54; James N. Anderson, "Calvinism and the First Sin," dalam ibid, 182-229; Welty, Why is There Evil, 106-115; Guillaume Bignon, Excusing Sinner and Blaming God: A Calvinist Assessment of Determinism, Moral
Kedua, tujuan dari penderitaan akibat COVID-19 ini adalah untuk membentuk karakter manusia dan membimbing mereka bertumbuh dari sikap mementingkan dan berpusat pada diri sendiri kepada sikap memusatkan perhatian kepada orang lain. Penderitaan dan kesakitan dapat membentuk kita memiliki karakter yang lebih matang dengan menjadi lebih sabar, pengasih, dan lebih peduli kepada orang-orang lain. ${ }^{44} \mathrm{Di}$ dalam penjelasan ini, penderitaan menjadi semacam gimnasium atau perapian yang membentuk kita menjadi baik dan murni dalam hal moral dan spiritual. Penderitaan menjadi semacam pendisiplinan dari Allah terhadap anak-anak-Nya agar anak-anak-Nya menjadi lebih dewasa dan matang (Ibr. 12:5-11). Meskipun tidak setiap penderitaan yang dialami oleh seseorang menghasilkan perubahan karakter, penderitaan karena COVID-19 dapat dipakai untuk membentuk kita menjadi lebih dewasa secara spiritual dan moral.

Ketiga, penderitaan karena COVID-19 adalah megafon dari Allah yang mengingatkan kita akan kerapuhan kita sebagai manusia dan kesementaraan dunia di mana kita tinggal sehingga kita bertobat dan berpaling kepada Allah untuk mencari kehidupan kekal. ${ }^{45}$ COVID-19 mengingatkan bahwa kita adalah manusia yang rapuh, yang memiliki relasi yang tidak benar dengan ciptaan dan dengan Pencipta, sehingga kita perlu berpaling kepada Sang Pencipta dan membangun relasi yang benar dengan Dia. Lennox menjelaskan:

Jika ini [COVID-19] menyebabkan kita memandang Allah yang mungkin kita abaikan selama bertahun-tahun, tetapi yang telah mengenakan mahkota duri demi membawa kita pulang ke dalam relasi dengan-Nya dan ke dalam dunia baru tanpa cacat dan kematian,

Responsibility, and Divine Involvement in Evil (Eugene: Pickwick, 2018), 184-228.

${ }^{41}$ Paul Helm, The Providence of God (Downers Grove: InterVarsity, 1993), 197.

${ }^{42}$ Welty, Why Is There Evil, 123-124.

${ }^{43} \mathrm{John}$ Piper, Coronavirus and Christ (Wheaton: Crossway, 2020), 71 .

${ }^{44}$ Welty, Why Is There Evil, 126.

${ }^{45}$ Ibid., 129; John C. Lennox, Where Is God In A Coronavirus World?, terj. Budianto Lim (Surabaya: Literatur Perkantas, 2020), 61. 
maka virus korona, meski mengacaukan tatanan hidup, akan melayani sebuah maksud yang sangat sehat." 46

Namun tidak semua penderitaan karena COVID19 ini adalah sebagai peringatan. Banyak orangorang Kristen yang sudah berpaling kepada Allah dan melayani Dia tetap mengalami penderitaan ini.

Keempat, kejahatan natural ini akan menimbulkan respons dan upaya untuk mengentaskan kejahatan ini. Respons dan upaya mengentaskan ini adalah kebaikan-kebaikan pada tingkat yang lebih tinggi (higher-order goods). Di dalam perspektif ini, beberapa kebaikan tidak dapat muncul jika tidak ada kejahatan yang muncul. Kebaikankebaikan ini adalah respons bahkan upaya untuk mengentaskan kejahatan natural tersebut. ${ }^{47} \mathrm{Sim}$ pati kepada yang sakit, belas kasihan kepada mereka yang menderita, kemurahan kepada orang yang malang (yang merupakan sifat-sifat yang baik) hanya akan muncul jika ada penderitaan dan kesakitan akibat kejahatan. Pengampunan terhadap orang yang bersalah kepada kita, menunjukkan sikap berterima kasih karena menerima pertolongan, memberikan penghargaan kepada orang yang telah melewati kesulitan hidup hanya bisa terjadi jika ada kejahatan yang terjadi. Kebaikan yang lebih tinggi ini hanya bisa terjadi jika ada kejahatan yang terjadi. ${ }^{48}$ Untuk kebaikan yang lebih tinggi inilah maka Allah mengizinkan kejahatan terjadi.

Namun kebaikan yang lebih tinggi ini bukan hanya berkaitan dengan manifestasi kebaikan manusia tetapi juga dengan kebaikan Allah. Allah mengizinkan kejahatan terjadi untuk menunjukkan kemuliaan-Nya. Ada kemuliaan

\footnotetext{
${ }^{46}$ Lennox, Where Is God, 61.

${ }^{47}$ Welty, Why Is There Evil, 132; Melville Y. Stewart, The Greater-Good Defence: An Essay on the Rationality of Faith (New York: Palgrave Macmillan, 1993), 15-16.

${ }^{48}$ Howard-Snyder, "God, Evil, and Suffering," 98.

${ }^{49}$ Pandangan ini disebut sebagai pembelaan kemuliaan Allah (divine glory defense). Lihat Johnson, "Calvinism and the Problem of Evil," 43-48. Termasuk di dalam pembelaan kemuliaan Allah ini adalah pandangan bahwa kemuliaan Allah terlihat di dalam inkarnasi dan penebusan sehingga penebusan mensyaratkan adanya kejahatan dalam bentuk kejatuhan
}

Allah, yakni natur dan sifat-sifat Allah yang agung, yang tidak dapat diperlihatkan atau dimanifestasikan di dalam ciptaan ini kecuali ada kejahatan yang harus dihukum, diampuni, dan dilenyapkan. ${ }^{49}$ Kemuliaan Allah dinyatakan dan diperlihatkan dengan jelas di dalam karya penebusan Yesus Kristus. Di dalam upaya Allah mengalahkan kejahatan, khususnya di dalam karya penebusan di dalam Kristus, Allah menunjukkan kasih, kuasa, dan hikmat-Nya (dengan kata lain kemuliaan-Nya) kepada manusia. Dari pemahaman ini maka kejahatan natural COVID-19 merupakan sarana Allah menunjukkan kemuliaanNya yakni keadilan Allah yang menghukum manusia berdosa, kuasa Allah atas alam semesta, serta Allah yang mengampuni orang-orang yang bertobat dan meninggalkan dosa-dosanya. Namun bukan setiap kejahatan akibat COVID-19 adalah untuk kemuliaan Allah. Kejahatan yang terjadi sering kali bukan sebagai hukuman (kasus Ayub dan orang yang lahir buta), namun kadangkadang sebagai ujian untuk membangun karakter dan kedewasaan spiritual, untuk mengingatkan kita akan kefanaan hidup dan Allah.

Masing-masing penjelasan-penjelasan yang diberikan memiliki keterbatasan, baik secara intrinsik karena keterbatasan konseptual di dalam penjelasan tersebut, maupun secara ekstrinsik karena Alkitab memberikan batasan kepada penjelasan tersebut dan memberitahu kita bahwa penjelasan tersebut tidak menjelaskan semua kejahatan yang ada. ${ }^{50}$ Penjelasan-penjelasan tersebut tidak dapat kita pakai sebagai satu penjelasan tunggal untuk kasus pandemi COVID-19 tetapi dapat kita pakai secara keseluruhan sebagai alasan-alasan yang paling mungkin. Di dalam kasus-kasus partikular COVID-19, salah satu atau semua penjelasanpenjelasan tersebut dapat diterapkan di dalam

manusia dalam dosa. Lih. Alvin Plantinga, "Supralapsarianism, or 'O Felix Culpa"' dalam The Problem Of Evil, edisi kedua, ed. Michael L. Peterson (Notre Dame: Unversity of Notre Dame, 2017), 363-386; Stewart, The Greater-Good Defence, 145; Ian Spencer, “A Mea Culpa For The Felix Culpa?” Lincoln University $1^{\text {st }}$ Annual Conference on Philosophy and Theology (2008): 15-16, diakses 12 November 2020, https://bluetiger commons.lincolnu.edu/philosophy_and theology/2008/sessio $\mathrm{ns} / 6$.

${ }^{50}$ Welty, Why Is There Evil, 135. 
kasus-kasus tersebut. Namun kadang kala kita tidak dapat menemukan alasan-alasannya dari keempat penjelasan tersebut untuk tiap-tiap kasus partikular. Ketidakmampuan kita di sini untuk menerapkan salah satu atau semua penjelasan tersebut kepada kasus COVID-19 tidak berarti tidak ada alasan mengapa Allah mengizinkan kejahatan natural ini. Mencampur keduanya sama dengan mencampuradukkan masalah epistemologi dan masalah metafisika. Mereka yang berpandangan tidak ada alasan Allah mengizinkan kejahatan natural ini terjadi memiliki beban pembuktian bahwa penjelasan-penjelasan tersebut tidak dapat diterapkan di dalam kasus pandemi dan kasuskasus partikular COVID-19. ${ }^{51}$

\section{YESUS KRISTUS DAN PROBLEM KEJAHATAN NATURAL COVID-19: ALLAH YANG MENDERITA DAN MENGALAHKAN KEJAHATAN}

Pengakuan kepada kedaulatan Allah di dalam kejahatan akan membawa kepada sikap berserah dan takluk kepada Allah sang penguasa tanpa dapat mempertanyakan apa alasan Allah. Sikap ini sukar dan kebanyakan ditemukan di kalangan orang yang benar-benar saleh bukan orang-orang yang biasa. Namun di dalam Alkitab, sikap ketaatan dan ketundukan kepada kedaulatan Allah yang berdaulat atas kejahatan bukan kebenaran akhir tentang kejahatan dan penderitaan. Kekristenan masih memberikan jawaban kepada problem kejahatan di dalam kristologi yakni di dalam inkarnasi dan penderitaan Yesus Kristus, pribadi kedua Allah Tritunggal. Peter Berger, seorang sosiolog, menjelaskan ini dengan baik: "it is crucial that the incarnate God is also the God who suffers. Without this suffering, without the agony of the

\footnotetext{
${ }^{51}$ Ibid., 139.

${ }^{52}$ Peter L. Berger, The Sacred Canopy: Elements of a Sociological Theory of Religion (New York: Open Road Media, 2011), 93, Adobe PDF book.

${ }^{53}$ Keller, Walking With God, 121.

${ }^{54}$ Thomas G. Weinandy, "Does God Suffer?" Ars Disputandi 2, no. 1 (2002): 7, diakses 20 November 2020, https://doi.org/10.1080/15665399.2002.10819720; lih. juga James E. Dolezal, "Strong Impassibility," dalam Divine Impassibility: Four Views on God's Emotion and Suffering, ed. Robert J. Matz dan A. Chadwick Thornhill (Downers Grove:
}

cross, the incarnation would not provide that solution of the problem of theodicy to which, we would contend, it owes its immense religious potency." 52 Di dalam kekristenan Allah yang berdaulat adalah Allah yang juga masuk ke dalam dunia dan turut merasakan penderitaan akibat kejahatan. Timothy Keller mengatakan: "Only Christianity, of all the world's major religions, teaches that God came to earth in Jesus Christ and became subject to suffering and death himself." 53

\section{Yesus Kristus sebagai Allah Yang Berinkarnasi dan Menderita Akibat Kejahatan}

Pada titik ini muncul pertanyaan: Apakah Allah dapat menderita? Penulis berpegang pada doktrin impasibilitas Allah (impassibility of God) yang berpendapat bahwa: "God is impassible in that he does not undergo successive and fluctuating emotional states, nor can the created order alter him in such a way so as to cause him to suffer any modification or loss. Nor is God the victim of negative and sinful passions as are human beings, such as fear, anxiety and dread, or greed, lust, and unjust anger." 54 Doktrin ini hendak mengatakan bahwa Allah bukan manusia yang sehingga Ia dibuat tidak berdaya atau dikuasai oleh emosi yang tidak terkontrol dan kuat seperti pada manusia atau dewa-dewa dalam mitologi Yunani Kuno. Allah bukan Allah yang terus berubah-ubah di dalam respons-Nya terhadap manusia dan situasi di dalam dunia ini. Doktrin ini hendak menyatakan bahwa Allah adalah Allah yang tetap setia dan teguh di dalam natur, sifatsifat, dan respons-Nya terhadap ciptaan Allah. ${ }^{55}$ Allah juga tidak dapat menderita dalam pengertian mengalami hambatan di dalam perkembangan

InterVarsity, 2019), 13-37. Pandangan yang mengakui bahwa Allah dapat mengalami perubahan emosi akibat pengaruh di luar diri Allah disebut sebagai pasibilitas Allah. Cendikiawan Kristen yang menganut pandangan ini antara lain: Karl Barth, Richard Bauckham, Paul Fiddes, Robert Jenson, Eberhard Jüngel, Kazoh Kitamori, Jürgen. Moltmann, Wolfhart Pannenberg, Richard Swinburne, Alan Torrance, Thomas F. Torrance, Keith Ward, Nicholas Wolterstorff, dan Hans Urs von Balthasar. Weinandy, "Does God Suffer?" 1-2.

${ }^{55}$ Campbell, Worldviews and The Problem of Evil, 242. 
seutuhnya karena Allah adalah sempurna dan apa yang Allah kehendaki tercapai di dalam kedaulatanNya. Namun doktrin ini tidak mengatakan bahwa Allah sama sekali tidak berespons terhadap manusia seperti Allah di dalam pemahaman kaum Stoic yang memiliki sifat apatheia yakni bersifat statis, tidak memiliki hidup yang dinamis, dan tidak peduli pada ciptaan-Nya. Allah sungguh berelasi dengan ciptaan-Nya, memiliki kasih, belas kasihan, dan panjang sabar.

Jika Allah tidak dapat menderita dan tidak berubah emosi-Nya karena pengaruh di luar diri-Nya maka bagaimana respons Allah terhadap kejahatan? Bagaimana Allah mengalami efek dari kejahatan terhadap diri-Nya? Menurut penulis ada tiga cara Allah mengalami penderitaan dan kesakitan akibat kejahatan yang terjadi. Pertama, Allah mengalami penderitaan sebagai respons emosi terhadap situasi dan kondisi manusia. Allah di dalam Alkitab adalah Allah yang memiliki emosi seperti belas kasihan, rahmat, kesabaran, bersuka cita, berkenan, senang, kasih, murka, cemburu, serta berduka (misalnya Ef. 4:30). Allah memiliki perasaan-perasaan terhadap ciptaan-Nya. Emosi-emosi Allah ini adalah "covenantal concern-based theodramatic construal." 56 Di sini emosi Allah dipahami sebagai pemahaman Allah yang bersifat evaluatif terhadap dunia atau manusia yang merupakan obyek kepedulian Allah di dalam konteks perwujudan ketetapan dan rencana Allah (baik yang menetapkan maupun yang mengizinkan) di dalam dunia serta di dalam perjanjian Allah dengan umat-Nya. Akibat kepedulian Allah di dalam konteks penciptaan dan kovenan maka pemahaman Allah terhadap kondisi manusia akan membawa respons emosi

\footnotetext{
${ }^{56}$ Kevin J. Vanhoozer, Remythologizing Theology: Divine Action, Passion, and Authorship (Cambridge: Cambridge University Press, 2010), 414. Penekanan oleh penulis buku. Harus diingat karena adanya perbedaan antara Pencipta dengan ciptaan maka ada perbedaan antara emosi manusia dengan Alllah. Selalu ada kesamaan dan kelebihan emosi ilahi dibandingkan dengan manusia.

${ }^{57}$ Ibid., 415. Penekanan oleh penulis buku.

${ }^{58}$ Kevin DeYoung, "Tis Mystery All, the Immortal Dies: Why the Gospel of Christ's Suffering is More Glorious Because God Does Not Suffer," 11, The Gospel Coalition, 2010, diakses 23 November 2020, https://blogs.thegospel coalition.org/kevindeyoung/files/2010/04/T4G-2010-KDYv_2.pdf
}

yang aktif. Respons emosi ini bukan pasif seolaholah Allah menjadi korban dari situasi di dalam dunia tetapi sebuah sikap afektif intensional dari Allah yang Ia pilih terhadap ciptaan-Nya. Respons emosi ini adalah respons aktif dari pemahaman evaluatif Allah yang obyektif dan selalu benar terhadap situasi yang telah Ia tetapkan sejak kekekalan. Kevin Vanhoozer menjelaskan: "God's construals are always true and his concerns constant-from which it follows, perhaps surprisingly, that God's feelings (i.e., his concern-imbued redemptive-dramatic construals) are as impassible as they are infallible: impassible feels." ${ }^{57}$ Namun karena situasi dunia dan kondisi manusia maka Allah yang tidak berubah akan memberikan respons yang berbeda tepat dan sesuai dengan situasi dan kondisi manusia. Kevin DeYoung menjelaskan:

\section{As we talk about God's emotional life we must keep this in mind: his changing external emotions are but a reflection of his inner, unchanging nature and character. These emo- tional "changes" in God relate to the temporal changes in his creatures. ${ }^{58}$}

Kedua, Allah turut merasakan penderitaan manusia melalui inkarnasi dan kematian Yesus Kristus sebagai pribadi kedua Allah Tritunggal. Yesus Kristus adalah pribadi kedua Allah Tritunggal yang sudah memiliki natur ilahi. Ia berinkarnasi menjadi manusia dengan menambahkan natur kemanusiaan pada natur Allah-Nya. Natur manusia Yesus dengan natur keilahian-Nya tidak terpisah dan tidak tercampur menjadi satu entitas baru. ${ }^{59}$ Dengan penambahan natur manusia ini maka Yesus Kristus sebagai pribadi kedua

\footnotetext{
${ }^{59} \mathrm{Di}$ sini penulis berbeda pendapat dengan Jessica Novia Layantara. Layantara berpendapat bahwa Yesus Kristus untuk dapat mengalahkan dan mengalami penderitaan menjadi manusia dan menjadi materi semua ciptaan seperti: awan, tanah, burung pipit, pohon, dan segalanya yang ada di alam semesta. Lih. Jessica Novia Layantara, "Kejahatan Tanpa Ampun Dan Inkarnasi Kristus," Stulos 17, no. 2 (Juli 2019): 258. Pandangan ini membawa masuk inkarnasi ke dalam konsep panenteisme di mana Allah adalah dan lebih besar dari alam semesta material ini serta bertentangan dengan konsili Chalcedon yang memelihara integritas masing-masing natur tanpa memisahkannya. Pandangan ini mengaburkan perbedaan kualitatif antara Pencipta dengan ciptaan. Lihat penjelasan Andrew Ter En Loke tentang kristologi dari konsili Chalcedon
} 
merasakan apa yang dirasakan oleh natur manusia Yesus Krisus. Jika natur manusia Yesus mengalami kesakitan, penderitaan, pengkhianatan, kematian, dan keterpisahan dengan Allah sebagai dampak kejahatan manusia maka hal-hal tersebut juga dialami oleh pribadi kedua Allah Tritunggal. Penderitaan tidak dapat dialami oleh natur ilahi Yesus Kristus karena natur ilahi tidak dapat menderita dan mengalami kematian. Sedangkan pribadi Yesus yakni Allah Anak yang menggerakkan atau menghidupi natur manusia Yesus Kristus dapat mengalami apa yang dialami oleh natur manusia Yesus. Hal ini dapat terjadi karena adanya konsep communicatio idiomatum yakni apa yang dialami oleh natur Allah dan natur manusia Yesus Kristus dapat diterapkan atau dipredikatkan kepada pribadi Anak Allah yang berinkarnasi. ${ }^{60}$ Karena konsep ini maka Yesus Kristus sebagai pribadi kedua Allah Tritunggal mengalami semua penderitaan dan kesakitan yang dialami oleh natur manusia Yesus Kristus. DeYoung menyatakan: "God as a man knew human pain and anguish first hand and in the same human manner that we experience it." ${ }^{\prime 61}$ Karena penderitaan ini maka Yesus Kristus dapat bersimpati kepada kita yang mengalami penderitaan dan kesakitan karena Ia sudah mengalami dan mengerti penderitaan tersebut secara langsung. Hal ini diperkuat dengan adanya penetrasi yang bersifat asimetris dari natur Allah terhadap natur manusia Yesus Kristus yang tidak melibatkan adanya pemindahan sifat-sifat atau atribut-atribut dari natur ilahi Yesus kepada natur

ini dalam A Kryptic Model of the Incarnation (New York: Ashgate, 2014), 70-73.

${ }^{60}$ Oliver D. Crisp, Divinity and Humanity: The Incarnation Reconsidered (Cambridge: Cambridge University Press, 2007), 5; Kevin DeYoung, "Divine Impassibility And The Passion Of Christ In The Book Of Hebrews," Westminster Theological Journal 68 (2006): 45. Martin Luther membawa doktrin communicatio idiomatum ini lebih jauh dengan mengajarkan bahwa terdapat pemindahan sifat-sifat atau atribut-atribut yang bersifat timbal balik dari natur keilahian Yesus kepada natur kemanusiaan Yesus dan juga sebaliknya (Crisp, Divinity and Humanity, 8-9). Pandangan Luther ini yang mempengaruhi pandangan bahwa Allah dapat menderita (passibilitas) dengan berpendapat bahwa natur keilahian Yesus Kristus juga mengalami penderitaan di dalam kesatuan hipostatik dengan natur kemanusiaan Yesus Kristus yang menderita. Karena itu, penderitaan kemanusiaan Kristus juga menunjukkan (bersifat mewahyukan) kehidupan internal Allah yang dapat menderita. Crisp kemanusiaan Yesus dan sebaliknya. ${ }^{62}$ Di sini natur ilahi dan kemanusiaan tidak bercampur dan menjadi satu entitas baru tetapi tetap berbeda dan memiliki sifat-sifat dari natur-natur tersebut masing-masing. Akibat penetrasi natur ilahi ke dalam natur manusia Yesus maka natur keilahian Yesus dapat memiliki akses langsung kepada pengalaman natur manusia Yesus di bumi ini. Ini berarti bahwa Anak Allah memiliki akses penuh kepada emosi, pengalaman, kesakitan, dan ketakutan yang di alami oleh natur manusia Yesus Kristus.

Ketiga, Allah turut merasakan penderitaan umatNya melalui kehadiran Roh Kudus yang menyatukan kita dengan Kristus sebagai kepala gereja. Roh Kudus berkarya di dalam kehidupan orang Kristen dengan menyatukan orang-orang Kristen dengan Yesus Kristus sehingga kita memiliki relasi dengan Yesus Kristus sebagai tubuh Kristus dengan kepala gereja. Roh Kudus bukan hanya menyatukan kita dengan Kristus tetapi juga mendiami kita sebagai orang-orang percaya. Kehadiran Roh Kudus berarti

"that God really may have specific empathy for each particular Christian, and therefore knows from the inside what it is like for you to suffer as you do. His knowledge of each in$d$ welt person means that he is able to meet the criteria for empathetically knowing what it is like to suffer what you have suffered." 63

menilai pandangan Luther tentang communicatio idiomatum ini keliru.

${ }^{61}$ DeYoung, "Divine Impassibility and The Passion," 56.

${ }^{62}$ Crisp, Divinity and Humanity, 19. Crisp menyebut ini sebagai perichoresis natur yang bersifat asimetris antara natur ilahi dan kemanusiaan Yesus.

${ }^{63}$ Scott Harrower, God of All Comfort: A Trinitarian Response to the Horrors of This World (Bellingham: Lexham, 2019), 62. Kehadiran Allah Roh Kudus di dalam diri orang percaya menjadikan interaksi personal antar pribadi manusia dengan Allah menjadi mungkin. Relasi interpersonal ini disebut sebagai second-personal presence oleh Eleonore Stump di mana Roh Kudus mendiami manusia sehingga Roh Kudus memiliki tingkat empati yang tinggi dalam sebuah relasi manusia. Stump menjelaskan: "And so in the indwelling of the Holy Spirit, God is present to a person of faith with maximal second-personal presence, surpassing even the presence possible between two human persons united in mutual love." Elenore Stump, "Omnipresence, Indwelling, And the Second- 
Relasi Yesus Kristus dengan umat-Nya melalui kehadiran Roh Kudus juga membuat Yesus Kristus mengidentifikasikan diri-Nya dengan umatNya sehingga penderitaan umat-Nya dialami oleh Yesus Kristus juga (Kis. 9:4). Dari pemaparan ini kita dapat melihat bahwa hanya Allah Tritunggal yang dapat bersimpati sepenuhnya terhadap manusia yang menderita akibat COVID-19 ini. Harrower menjelaskan:

God can empathize with human persons with a full-orbed empathy because he is a Trinitarian God. If he were not Trinitarian, he could not have the degree of empathy whereby he is 'attuned and responsive to the affective states of those with whom they empathize." 64

\section{Yesus Kristus Sebagai Allah Mengalahkan Kejahatan dengan Kejahatan}

Allah Tritunggal bukan hanya merasakan dan mengetahui penderitaan manusia tetapi Allah juga bertindak masuk ke dalam dunia yang mengalami kesengsaraan untuk mengalahkan kejahatankejahatan tersebut. Alkitab memberikan pengharapan akan adanya pemusnahan kejahatan dengan kehadiran kerajaan Allah di mana Allah memerintah. Dengan datangnya kerajaan Allah maka ciptaan Allah akan sepenuhnya dihilangkan dari segala macam kejahatan. Perjanjian Lama khususnya para nabi-nabi PL menggambarkan kedatangan kerajaan Allah "includes the victory over evil, over error and war, sin and penalty, sickness and death." ${ }^{65}$ Di dalam pelayanan Yesus Kristus, Kerajaan Allah telah datang. Ia makan dan minum bersama dengan orang-orang berdosa, Ia mengusir dan menaklukkan roh-roh jahat dan setan, Ia menyembuhkan orang-orang yang sakit dan membangkitkan orang mati serta Ia berkuasa

Personal" European Journal for Philosophy of Religion 5, no. 4 (2013): 51, https://doi.org/10.24204/ejpr.v5i4.204.

${ }^{64}$ Ibid. Di sini Harrower mengutip Hourdequin, "Empathy, Shared Intentionality, and Motivation," 409.

${ }^{65}$ Henry Blocher, Evil and the Cross, terj. David G. Preston (Downers Grove: InterVarsity, 1994), 107.

${ }^{66}$ Alexander D. Limasaputra, "Memandang Penderitaan Melalui Perspektif The Already and The Not Yet dari Rasul Paulus" Veritas: Jurnal Teologi dan Pelayanan 17, no. 1 (Juni 2018): 48, https://doi.org/10.36421/veritas.v17i1.305; Tan Kian Guan, "Kebenaran Doktrin Antropologi dan Soteriologi atas alam dengan meneduhkan angin badai. Penulis Injil Markus berkata: "Ia menjadikan segala-galanya baik, yang tuli dijadikan-Nya mendengar, yang bisu dijadikan-Nya berkatakata" (Mrk. 7:37), yang menunjukkan pembaruan terhadap manusia dan ciptaan sudah dimulai bersama Yesus Kristus. Kekalahan kejahatan terlihat dengan jelas di atas kayu salib. Di kayu salib Yesus Kristus mengalahkan dosa dan kematian, serta menghancurkan pekerjaan Iblis, dan antekanteknya. Karya Kristus di atas Salib ini juga memiliki dampak kosmik yakni mulai terjadinya pembaruan ciptaan yang pada akhirnya menjadi langit dan bumi yang baru. Langit dan bumi yang baru sebagai tempat yang sepadan dengan manusia yang telah mengalami pembebasan dari dosa dan penebusan di dalam Kristus. ${ }^{66}$ Di salib, kejahatan dikalahkan sebagai kejahatan. Blocher menjelaskan:

Evil is conquered as evil because God turns it back upon itself. He makes the supreme crime, the murder of the only righteous person, the very operation that abolishes sin. The manoeuvre is utterly unprecedented. No more complete victory could be imagined. ... God entraps the deceivers in his own wiles. Evil, like a judoist, take advantage of the power of the good, which it perverts; the Lord, like a supreme champion, replies by using the very grip of the opponent. ${ }^{67}$

Kejahatan memang tidak sepenuhnya hilang setelah penyaliban dan kebangkitan Yesus Kristus. Kita masih mengalami kejahatan, baik moral maupun natural. Bahkan kita sekarang mengalami penularan COVID-19 yang berskala global dan hampir semua umat manusia di muka bumi ini merasakan penderitaan akibat COVID-19 ini.

bagi Kepentingan Etika Lingkungan" Veritas: Jurnal Teologi dan Pelayanan 13, no. 2 (2012): 209-212, https://doi. org/10.36421/veritas.v13i2.264.

${ }^{67} \mathrm{Blocher}$, Evil and the Cross, 132 . Tentu saja karya Kristus di atas kayu salib bukan sekedar mengalahkan kejahatan tetapi juga menjadi kurban pengganti manusia berdosa sehingga manusia dapat disucikan dari dosa dan dapat menjadi benar di hadapan Allah. Untuk tulisan yang baik sekali tentang karya Kristus di salib lihat William Lane Craig, Atonement and the Death of Christ: An Exegetical, Historical, and Philosophical Exploration (Waco: Baylor University, 2020). 
Di sini kita perlu memahami bahwa ada ketegangan antara yang sudah tercapai dan yang belum terealisasi sepenuhnya. Kerajaan Allah memang sudah datang dan kejahatan sudah dikalahkan tetapi realisasi yang penuh dari kerajaan Allah dan kemenangan final terhadap kejahatan akan terjadi ketika Yesus Kristus datang untuk yang kedua kalinya melakukan pembaruan kosmis yang tuntas. Konsep seperti ini disebut juga dengan konsep kerajaan Allah yang sudah datang tetapi belum sepenuhnya terealisasi (already and not yet).$^{68}$ Pada kedatangan Kristus, kemenangan final terhadap kejahatan terjadi dengan adanya penghakiman atas kejahatankejahatan manusia dan pembaharuan atas alam semesta terjadi. Apa yang rusak dan hilang karena kedatangan kejahatan di dalam dunia akan segera direstorasi kembali pada saat itu. Manusia dapat menghukum kejahatan akan tetapi manusia tidak dapat merestorasi dampak dari kejahatan. Keller mengatakan: "while we can punish evil, we cannot undo evil ... it is [Jesus Christ] who now is able not simply to judge wrongdoing but actually to undo the damage that evil has wreaked on the creation." "Ciptaan akan dibebaskan dari perbudakan terhadap proses kebinasaan dan kematian (Rm. 8:19-21) dan "maut tidak akan ada lagi; tidak akan ada lagi perkabungan, atau ratap tangis, atau dukacita, sebab segala sesuatu yang lama itu telah berlalu" (Why. 21:4).

\section{SIKAP ETIS TRINITARIAN TERHADAP COVID-19}

\section{Roh Kudus Menghibur dan Memberi Kuasa Melawan Kejahatan Natural COVID-19}

Karya Yesus Kristus mengalahkan kejahatan di salib dan melalui kebangkitan-Nya membuat kita menyadari bahwa kejahatan dan penderitaan secara intrinsik adalah salah dan jahat oleh sebab itu perlu kita berupaya untuk mengentaskannya. Allah memiliki rencana untuk mengadakan pembaharuan terhadap ciptaan-Nya yang telah rusak

\footnotetext{
${ }^{68}$ Ibid., 119-121; Limasaputra, "Memandang Penderitaan Melalui Perspektif," 45.

${ }^{69}$ Keller, Walking with God, 155-156. Penekanan oleh penulis buku.
}

oleh kejahatan dan dosa manusia. Rencana Allah ini adalah menciptakan suatu umat Allah yang hidup di hadirat Allah, dengan aturan-aturan Allah dan di tempat yang Allah mau yakni bumi dan langit yang telah di restorasi. Untuk menghadirkan umat manusia yang mau hidup dengan aturan dan cara Allah ini maka peran Roh Kudus menjadi penting di sini. ${ }^{70}$ Roh Kudus yang diutus oleh Bapa dan Anak melanjutkan misi dari Yesus Kristus untuk menghadirkan kerajaan Allah dan memperbaharui ciptaan serta mengentaskan kejahatan baik moral maupun natural. Roh Kudus bekerja dengan menciptakan dan memasukkan orang-orang berdosa ke dalam umat pilihan-Nya sebagai anggota keluarga Allah. Orang-orang yang dipilih bukan hanya untuk menerima berkat keselamatan hasil karya Tuhan Yesus tetapi juga untuk sebuah tujuan yakni ikut serta dalam rencana Allah untuk memperbaharui ciptaan dengan mengenyahkan kejahatan yang dimulai dengan pembaharuan hati manusia sebagai sumber dosa dan kejahatan moral yang berdampak kepada tatanan alam. Harrower menjelaskan: "In the context of the kingdom of God, Jesus' disciples can represent him and his care to one another. God deputizes his images in order to make his character and engagement with a suffering world visible and available." $"$ Allah memilih gereja yang di dalam dan melalui kuasa Roh Kudus untuk menghadapi kejahatan, baik moral dan natural, di dalam dunia ini.

\section{Misi Gereja di dalam Dunia yang Menderita}

Pada momen Pentakosta, Yesus Kristus membaptis sekelompok manusia yakni para murid-Nya dengan Roh Kudus untuk dimasukkan ke dalam tubuh Kristus dan memiliki relasi dengan Kristus secara spiritual. Akibat baptisan ini maka Roh Kudus mendiami manusia dan tinggal di dalam hati manusia. Umat Allah, yang kita kenal dengan gereja, masuk dalam misi pemulihan ciptaan oleh Roh Kudus yang dimulai dengan pemberitaan Injil yang sanggup mengubah hati manusia yang

\footnotetext{
${ }^{70}$ Graham Cole, He Who Gives Life (Wheaton: Crossway, 2007), 209.

${ }^{71}$ Harrower, God of All Comfort, 65.
} 
berdosa dan jahat. Dengan demikian Pentakosta bukan sebuah peristiwa yang terpisah dari salib dan kebangkitan Yesus Kristus tetapi merupakan salah peristiwa puncak di dalam sejarah keselamatan. ${ }^{72}$ Gereja yang dimasukkan ke dalam rencana kekal Allah diutus kembali ke dalam dunia yang menderita ini dengan sebuah misi.

Misi gereja di dalam dunia yang menderita ini adalah, pertama, memperantarai kehadiran Allah. Gereja merupakan tubuh Kristus yang kelihatan di dunia ini dan melalui gereja Yesus Kristus bertindak. Orang-orang Kristen merupakan medium dari realitas kerajaan Allah yang dimunculkan kepada mereka yang tinggal di dalam dunia yang menderita ini. Melalui aksi gereja Yesus Kristus membuat perubahan di dalam dunia ini. Orangorang Kristen menghadirkan Allah melalui tindakan, perkataan, dan sikap mereka seharihari. Anthony Kelly menjelaskan: "Christian community lives the presence of Christ performatively, so to speak, through the mediations of liturgy and preaching, in its missionary outreach and dialogical encounters, in its serving Christ in the neighbor, and in loving him even in the enemy." 73 Di sini Roh Kudus mengarahkan gereja untuk memperagakan realitas kerajaan Allah di dalam dunia ini dalam bentuk empati, perhatian dan tindakan di dalam dunia.

Kedua, gereja punya misi untuk memperantarai perspektif Allah. Perspektif Allah terhadap kejahatan bukan hanya diperlihatkan melalui providensi Allah yang mengizinkan kejahatan untuk kebaikan yang lebih besar tetapi juga melalui perspektif Yesus Kristus terhadap kejahatan. Yesus Kristus menangis karena kematian sahabatNya Lazarus (Yoh. 11:33-35) dan Ia tergerak oleh belas kasihan kepada orang-orang yang terlantar dan menderita (Mat. 9:36; 14:14). Yesus juga marah terhadap pemimpin-pemimpin agama yang menyalahgunakan agama untuk kepentingan pribadi. Singkatnya, Yesus melihat kejahatan seba-

\footnotetext{
${ }^{72}$ Cole mengatakan bahwa Pentakosta masuk ke dalam historia salutis (sejarah keselamatan) dan bukan ordo salutis (urutan cara orang mengalami keselamatan). Konsekuensinya Pentakosta bukan bicara berkat kedua setelah keselamatan tetapi bicara tentang "the birth of 'the body of Christ, ' ... beginning with 'the restored remnant of Israel' and extending thence
}

gai sesuatu yang jahat secara intrinsik dan perlu dikonfrontasi. Orang-orang Kristen berfungsi sebagai saluran yang menyalurkan perspektif Allah tentang kejahatan, kehidupan, dan menjadi terang kepada orang-orang lain.

Ketiga, gereja berperan untuk memperantarai aksi-aksi Allah pada masa kini. Allah bertindak mengalahkan kejahatan dan melakukan pembaruan ciptaan. Sebagai tubuh Kristus, gereja perlu melanjutkan aksi-aksi Allah ini di dalam dunia nyata. Gereja perlu bekerja untuk mewujudkan kehendak Allah di bumi dan menunjukkan perhatian kepada sesama yang menderita. Tindakantindakan tersebut seperti memberi makan kepada yang lapar dan haus, memberi tumpangan, memberi pakaian, memberi perhatian kepada yang sakit dan yang ada dalam penjara (Mat. 25:3536). Harrower menyimpulkan: "As a body of people whose life is patterned after Jesus, we will empathetically mirror his attention toward others, and so the church will reach out to the world in a manner that is best described as service." 74

Keempat, gereja menjadi perantara penghiburan Allah. Oramg-orang yang menderita dan mengalami kesakitan membutuhkan kata-kata penghiburan yang berasal dari kata-kata Kristus yang menghibur dan menguatkan. Gereja berperan memperantarai penghiburan dari Kristus kepada orangorang lain yang menderita. Dietrich Bonhoeffer menjelaskan hal ini demikian:

"Help can only come from the outside; and it has come and comes daily and anew in the Word of Jesus Christ. ... God put His Word into the mouth of human beings in order that it may be communicated to others. Therefore, Christians need other Christians who speak God's Word to them. They need them again and again when they become uncertain and discouraged." 75

to the world of the Gentile in fulfillment of the ancient Abrahamic promises." Lih. Cole, He Who Gives Life, 212.

${ }^{73}$ Dikutip dari Harrower, God of All Comfort, 70.

${ }^{74}$ Ibid., 73-74.

${ }^{75}$ Dikutip dari ibid., 74. 


\section{Roh Kudus yang Menghibur dan Memberi Kuasa}

Pada waktu gereja masuk ke dalam dunia dan mengentaskan kejahatan, gereja sendiri akan menghadapi kejahatan, baik moral maupun natural, dan akan mengalami penderitaan, kesakitan, dan penganiayaan dari orang-orang yang menentang gereja Tuhan. Di sini Roh Kudus berperan sebagai penghibur kita. Ia disebut juga sebagai Penghibur atau Pendamping (parakletos) yang menyertai kita di dalam menghadapi penderitaan dan penganiayaan di tengah-tengah misi kita. Gereja tidak pernah berjuang dengan kekuatannya sendiri untuk memberi hidup, bekerja memperbarui manusia dan tatanan ciptaan, serta melawan kejahatan. Gereja memiliki Roh Kudus yang memberikan penghiburan karena kehadiran-Nya yang menyertai gereja di dalam penganiayaan. ${ }^{76}$ Lebih jauh lagi, Roh Kudus yang diam di dalam hati orang percaya juga membantu orang-orang percaya untuk berdoa kepada Allah Bapa bahkan berdoa untuk orang-orang percaya di tengahtengah kelemahan dan penderitaan mereka (Rm. 8:26). Roh Kudus berdoa kepada Bapa dengan menyampaikan penderitaan dan kesakitan kita kepada Bapa. ${ }^{77}$

Gereja bukan hanya diberi penghiburan di tengah penderitaan yang harus dialaminya tetapi juga diberi kuasa oleh Roh Kudus untuk menjalankan misi Allah. Campbell menjelaskan:

"As the redeemed community of Christ, then, it is the Spirit who is the agent of change, and it is he who provides the church with the power to make a difference and to confront the evil in the world. Through the Spirit, God has supplied all the power and energy needed to truly be agents and ambassadors of reconciliation." 78

Kuasa ini yang membuat komunitas Kristen berbeda dengan lembaga-lembaga karitas yang lain.

\footnotetext{
${ }^{76}$ Michael Horton, Rediscovering the Holy Spirit (Grand Rapids: Zondervan, 2017), 126.
}

Kuasa ini yang memberikan keberanian dan kekuatan bagi gereja untuk mengentaskan kejahatan di mana saja itu berada, baik di dalam struktur sosial, level personal, maupun yang terjadi ketika tatanan natural tidak bersahabat dengan manusia. yakni penderitaan karena COVID-19. Adalah tugas gereja untuk menunjukkan kasih dan perhatian kepada mereka yang menderita akibat pandemi ini.

\section{KESIMPULAN}

COVID-19 menghadirkan pertanyaan metafisika dan moral tentang kejahatan natural. Mengapa ada kejahatan natural, apa tujuan kejahatan natural, dan akhir dari kejahatan natural. Bagaimana respons orang-orang Kristen terhadap keberadaan kejahatan natural ini? Menjawab pertanyaan tersebut penulis memaparkan bahwa kejahatan natural merupakan akibat dari kejatuhan manusia ke dalam dosa. Akibatnya proses natural sudah tidak berjalan sebagaimana mestinya seperti dalam rancangan Allah yang baik. Kejahatan natural diizinkan Allah untuk terjadi di dalam providensi-Nya untuk kebaikan yang lebih besar. Kebaikan yang lebih besar tersebut adalah untuk menghukum dosa manusia, untuk membentuk karakter manusia menjadi lebih baik, untuk mengingatkan manusia akan Allah dan kehidupan kekal mendatang, serta untuk menghasilkan kualitas-kualitas kebaikan tingkat lebih tinggi sebagai respons terhadap adanya kejahatan. Kita tidak dapat menerapkan penjelasan-penjelasan tersebut kepada pandemi COVID-19 secara global maupun kepada kasus-kasus partikular COVID-19 secara pasti namun penjelasan-penjelasan tersebut secara keseluruhan atau secara satu persatu dapat menjadi penjelasan yang paling mungkin terhadap adanya kejahatan COVID-19 ini. Di dalam penjelasan seperti ini maka kejahatan memiliki makna di dalam rencana Allah dan Allah yang bertindak sebagai Bapa memiliki kedaulatan atas kejahatan.

\footnotetext{
${ }^{77}$ Timothy Wiarda, "What God Knows When the Spirit Intercedes" Bulletin for Biblical Research 17, no. 2 (2007): 305, https://www.jstor.org/stable/26423927.

${ }^{78}$ Campbell, Worldviews and the Problem of Evil, 251-252.
} 
Penulis juga menjelaskan bahwa inkarnasi Allah Anak ke dalam dunia menjadikan Yesus, sebagai pribadi kedua Allah Tritunggal, mampu bersimpati kepada manusia yang menderita karena Ia memiliki natur manusia yang menderita dan mati. Karya Kristus di dalam dunia dan salib-Nya memperlihatkan kejahatan sebagai kejahatan secara intrinsik. Karena kejahatan adalah jahat maka Yesus Kristus melawan kejahatan dan mengalahkan kejahatan di atas kayu salib. Inkarnasi, pelayanan, penderitaan, kematian, dan kebangkitan Yesus menunjukkan bahwa Allah bertindak untuk mengentaskan kejahatan yang akan mencapai finalnya pada saat penghakiman terakhir ketika Yesus Kristus datang ke dalam dunia untuk yang kedua kalinya. Sebagai kelanjutan dari pelayanan Yesus Kristus di dunia ini, gereja Tuhan harus melanjutkan pelayanan Yesus yang mengentaskan kejahatan. Gereja yang lahir pada momen Pentakosta diberikan penghiburan dan kuasa oleh Roh Kudus untuk menjalankan misi tersebut. Secara singkat, providensi Allah, inkarnasi dan pelayanan serta penderitaan Yesus Kristus menjawab permasalahan metafisika kejahatan natural, sedangkan karya Roh Kudus dan misi gereja menjawab permasalahan moral dari kejahatan natural COVID-19.

\section{REFERENSI}

Adam, Marilyn McCord. Christ and Horrors: The Coherence of Christology. Cambridge: Cambridge University Press, 2006.

Alexander, David E. dan Daniel M. Johnson, ed. Calvinism and the Problem of Evil. Eugene: Pickwick, 2016.

Alinurdin, David. "COVID-19 dan Tumit Achilles Iman Kristen." Veritas: Jurnal Teologi dan Pelayanan 19, no. 1 (Juni 2020): 1-9. https://doi.org/10.36421/veritas. v19i1.373.

Berger, Peter L. The Sacred Canopy: Elements of a Sociological Theory of Religion. New York: Open Road Media, 2011. Adobe PDF book.

Bignon, Guillaume. Excusing Sinner and Blaming God: A Calvinist Assessment of Determinism, Moral Responsibility, and Divine Involvement in Evil. Eugene: Pickwick, 2018.
Blocher, Henry. Evil and the Cross. Terj. David G. Preston. Downers Grove: InterVarsity, 1994.

Campbell, Ronnie P. Worldviews and Problem of Evils: A Comparative Approach. Bellingham: Lexham, 2019. Logos Bible Software.

Carson, Donald A. "Biblical-Theological Pillars Needed to Support Faithfull Christian Reflection on Suffering and Evil." Trinity Journal 38NS, no 1 (2017): 55-77.

Chakraborty, Indranil. dan Prasenjit Maity, "COVID-19 Outbreak: Migration, Effects on Society, Global Environment and Prevention." Science of Total Environment 728 (2020): 1-7. Diakses 9 Oktober 2020. https:// doi.org/10.1016/j.scitotenv.2020.138882.

Cole, Graham. He Who Gives Life. Wheaton: Crossway, 2007.

Collins, C. John. Science and Faith: Friends or Foes? Wheaton: Crossway, 2003.

Craig, William Lane. Atonement and the Death of Christ: An Exegetical, Historical, and Philosophical Exploration. Waco: Baylor University, 2020.

Crisp, Oliver D. Divinity and Humanity: The Incarnation Reconsidered. Cambridge: Cambridge University Press, 2007.

DeYoung, Kevin. "Divine Impassibility And The Passion Of Christ In The Book Of Hebrews." Westminster Theological Journal 68 (2006): 41-50.

. "Tis Mystery All, the Immortal Dies: Why the Gospel of Christ's Suffering is More Glorious Because God Does Not Suffer," The Gospel Coalition, 2010, 1-15. Diakses 23 November 2020. https://blogs. thegospelcoalition.org/kevindeyoung/files/2 010/04/T4G-2010-KDY-v_2.pdf.

Dolezal, James E. "Strong Impassibility." Dalam Divine Impassibility: Four Views on God's Emotion and Suffering, ed. Robert J. Matz dan A. Chadwick Thornhill, 13-37. Downers Grove: InterVarsity, 2019.

Erickson, Millard J. Christian Theology. Edisi ketiga. Grand Rapids: Baker, 2013.

Feinberg, John S. No One Like Him. Wheaton: Crossway, 2001. 
The Many Faces of Evil: Theological Systems and the Problems of Evil. Edisi revisi. Wheaton: Crossway, 2004.

Frame, John M. Apologetics: A Justification of Christian Belief. Edisi kedua. Diedit oleh Joseph E. Torres. Phillipsburg: P\&R, 2015.

—. "The Problem of Evil" Dalam Suffering and the Goodness of God, diedit oleh Christopher W. Morgan dan Robert A. Peterson, 141-164. Wheaton: Crossway, 2008.

Francis, Joe. "Good Design Gone Bad.” Answers in Genesis, Oktober 2011. Diakses 1 Juni 2020. https://answersingenesis.org/evidencefor-creation/design-in-nature/good-designsgone-bad.

Gooding, David dan John Lennox, Suffering Life's Pain: Facing the Problems of Moral and Natural Evil. Belfast: Myrtlefield, 2019.

Harrower, Scott. God of All Comfort: A Trinitarian Response to the Horrors of This World. Bellingham: Lexham, 2019.

Hart, Matthew James. "Theological Determinism and the Goodness of God." Disertasi, University of Liverpool, 2019.

Helm, Paul. The Providence of God. Downers Grove: InterVarsity, 1993.

Hick, John. Evil and the God of Love. New York: Palgrave Macmillan, 2010.

Horton, Michael. Rediscovering the Holy Spirit. Grand Rapids: Zondervan, 2017.

Howard-Snyder, Daniel. "God, Evil, and Suffering." Dalam Reason for the Hope Within, diedit oleh Michael J. Murray, 76-115. Grand Rapids: Eerdmans, 1999.

Inman, Ross. "Gratuitous Evil Unmotivated: A Reply to MacGregor." Philosophia Christi 15, no. 2 (2013): 435-445. Diakses 9 November 2020. https://doi.org/10.5840/ pc201315237.

Keller, Timothy. Walking with God through Pain and Suffering. London: Hodder \& Stoughton, 2013.

Layantara, Jessical Novia. "Kejahatan Tanpa Ampun Dan Inkarnasi Kristus.” Stulos 17, no. 2 (Juli 2019): 241-264.

Lennox, John C. Where Is God In A Coronavirus World? Terj. Budianto Lim. Surabaya: Literatur Perkantas, 2020.
Limasaputra, Alexander Darmawan. "Memandang Penderitaan Melalui Perspektif The Already and The Not Yet dari Rasul Paulus." Veritas: Jurnal Teologi dan Pelayanan 17, no. 1 (Juni 2018): 43-60. https://doi.org/10. 36421/veritas.v17i1.305.

Loke, Andrew Ter En. A Kryptic Model of the Incarnation. New York: Ashgate, 2014.

Meister, Chad V. Evil: A Guide for the Perplexed. Edisi kedua. New York: Bloomsbury, 2018.

Meister, Chad V. dan James Dew Phillip, ed. God and the Problem of Evil: Five Views. Downers Grove: InterVarsity Press, 2017. Kindle.

Ortlund, Gavin. "On the Fall of Angels and the Fallenness of Nature: An Evangelical Hypothesis Regarding Natural Evil." Evangelical Quarterly 87, no. 2 (2015): 114-136.

Piper, John Piper. Coronavirus and Christ. Wheaton: Crossway, 2020.

Plantinga, Alvin. "Supralapsarianism, or 'O Felix Culpa." Dalam The Problem Of Evil, edisi kedua, diedit oleh Michael L. Peterson, 363389. Notre Dame: Unversity of Notre Dame, 2017.

- God, Freedom, and Evil. Grand Rapids: Eerdmans, 1977.

- Warranted Christian Belief. Oxford: Oxford University Press, 2000.

Spencer, Ian. "A Mea Culpa For The Felix Culpa?" Lincoln University 1st Annual Conference on Philosophy and Theology (2008): 1-17. Diakses 12 November 2020. https://bluetigercommons.lincolnu.edu/phil osophy_and_theology/2008/sessions/ 6 .

Stewart, Melville Y. The Greater-Good Defence: An Essay on the Rationality of Faith. New York: Palgrave Macmillan, 1993.

Stump, Eleonore. "Suffering and Flourishing." Makalah yang dipresentasikan pada Kuliah M.Th, Singapore Bible College, 21 September 2020.

-. "Omnipresence, Indwelling, And the Second-Personal." European Journal For Philosophy Of Religion 5, no. 4 (2013): 29-53. https://doi.org/10.24204/ejpr.v5i4.204.

. Wandering in Darkness: Narrative and the Problem of Suffering. Oxford: Clarendon Press, 2010. 
Tan, Kian Guan. "Kebenaran Doktrin Antropologi dan Soteriologi bagi Kepentingan Etika Lingkungan." Veritas: Jurnal Teologi dan Pelayanan 13, no. 2 (2012): 203-216. https://doi.org/10.36421/veritas.v13i2.264.

Vanhoozer, Kevin J. Remythologizing Theology: Divine Action, Passion, and Authorship. Cambridge: Cambridge University Press, 2010.

van Inwagen, Peter. The Problem of Evil. Oxford:

Clarendon, 2008.
Weinandy, Thomas G. "Does God Suffer?" Ars Disputandi 2, no. 1 (2002): 1-13. Diakses 20 November 2020. https://doi.org/10.1080/ 15665399.2002.10819720.

Welty, Greg. Why is There Evil in the World (And so Much of it)? Ross-shire: Christian Focus, 2018.

Wiarda, Timothy. "What God Knows When the Spirit Intercedes." Bulletin for Biblical Research 17, no. 2 (2007): 297-311. https:// www.jstor.org/stable/26423927. 
